大前 宣昭*1,2 ·三尾 典克*1,3

\title{
Characteristics of Laser System Used in Large-Scale Cryogenic Gravitational Wave Telescope
}

\author{
Noriaki OHMAE*1,2 and Norikatsu MIO*1,3
}

\begin{abstract}
*1Department of Advanced Materials Science, University of Tokyo, 5-1-5 Kashiwanoha, Kashiwa, Chiba 277-8561, Japan ${ }^{* 2}$ Current address: Department of Applied Physics, University of Tokyo, 7-3-1 Hongo, Bunkyo-ku, Tokyo 113-8656, Japan ${ }^{* 3}$ Current address: Photon Science Center, University of Tokyo, 2-11-16 Yayoi, Bunkyo-ku, Tokyo 113-8656, Japan
\end{abstract}

(Received June 30, 2011, Accepted September 22, 2011)

\begin{abstract}
In order to detect a gravitational wave, a kilometer-scale interferometer with a high-power, single-frequency laser with extremely low noises is required. In the Japanese gravitational wave detector named Large-scale Cryogenic Gravitational wave Telescope (LCGT), a single-frequency laser with an output power of more than $100 \mathrm{~W}$ will be used. The laser system used in LCGT consists of a master laser, an amplifier, a pre-modecleaner, a modulation system, and a modecleaner. The system also includes stabilization systems for laser intensity and frequency. We have already developed most of them. This article describes the characteristics of the laser system used in LCGT and the current status of our developments.
\end{abstract}

\section{1. はじめに}

重力波をとらえるために, Fig. 1 に示すようなレーザー 干渉計型の重力波検出器が世界各地に建設されている. 干渉 計を構成する鏡は振り子で懸架されており，その共振周波数 以上の周波数では自由質量として振る舞う。この干渉計に重 力波がやってくると, 重力波の振動数に合わせて, 干渉計の 直交した 2 本の腕の長さが差動で変動する. 重力波による 干渉計の 2 本の腕の長さの差動の変動を, 干渉縞の強度の 変化として検出することにより, 重力波を見ることができ る. しかし, 干渉計の腕の長さに対する重力波による腕の長 さの变化 $\delta L$ は, $\delta L / L \approx 10^{-21}$ と程度と非常に小さいため に, 重力波を検出するためには, 非常に長い腕をもつ干渉計 を必要とする．2010年からスタートした日本の重力波検出 器「大型低温重力波望遠鏡 (Large-scale Cryogenic Gravitational wave Telescope, LCGT)」計画では, 腕の長さが $L=$ $3 \mathrm{~km}$ の大きなレーザー干渉計を神岡鉱山の地下に建設する.

\section{2. 大型低温重力波望遠鏡で必要とされるレー ザー光源}

レーザー干渉計において，レーザーは物差しと考えるとよ い.レーザーの波長を物差しとして用いて， 2 本の腕の長さ の差動の変動を見る. 一般に, 干渉計測用のレーザー光源に は, 単一空間モード, 単一周波数で連続発振するレーザーが 用いられる. さらに, 偏光状態が安定で, 強度や周波数の摇 らぎが小さいことが必要とされる. 重力波検出器で用いる レーザー光源にも同様の要求が課されるが, 通常の場合の光 源と比べて, 高出力で強度や周波数の摇らぎが極端に小さく

* 平成23年 3 月 9 日 第58回応用物理学関係連合講演会で発表

*1 東京大学大学院新領域創成科学研究科物質系専攻 (干277-8561 千葉県柏市柏の葉 5-1-5)

*2 現在 : 東京大学大学院工学系研究科物理工学専攻 (₹113-8656 東京都文京区本郷 7-3-1)

*3 現在: 東京大学大学院工学系研究科附属光量子科学研究セン ター(テ113-8656 東京都文京区弥生 2-11-16)

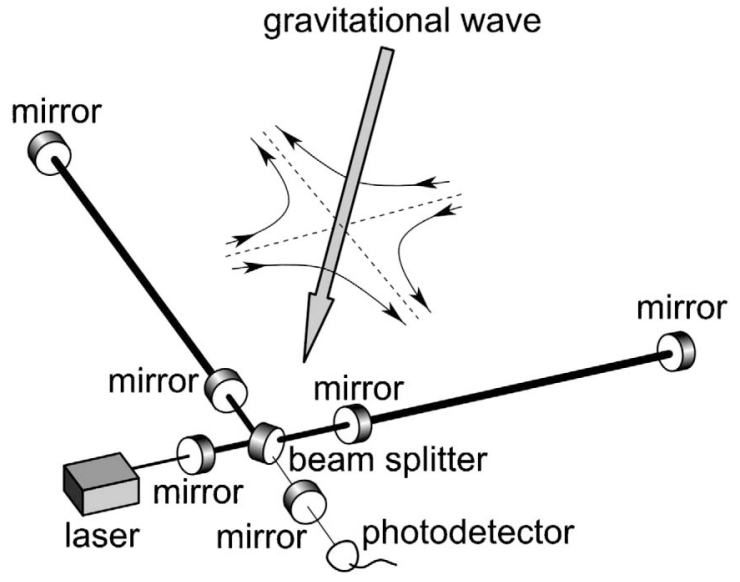

Fig. 1 Laser interferometric gravitational wave detector.

なくてはいけないということが挙げられる. というのは, 重 力波の効果が非常に微弱なためで, 極めて小さな干渉縞の变 化量を読久取るためには, 光源のパワーで決まるショット雑 音のレベルを下げなければならないからである.ショット雑 音は，レーザーが干渉計に入射するポートとは反対のポート から入射する真空場の摇らぎがもたらすと考えることができ る（Fig. 2). マイケルソン干渉計に拈いて，波長 $\lambda$, パワー Pのレーザーを用いた場合のショット雑音による干渉縞の読 み取り限界は,

$$
\delta \phi_{\text {shot }}=\sqrt{\frac{4 \pi \hbar c}{\lambda P} \Delta f}
$$

で表される1).ここで, $c$ は光速, $\hbar$ はプランク定数, $\Delta f$ は 測定の帯域幅である。ショット雑音による読み取り限界は, レーザーパワーPの平方根に反比例するため, レーザーパ ワーPを大きくすることで, 読み取り精度が向上する. 式 (1) に対して, $\delta \phi_{\text {shot }}=10^{-10} \mathrm{rad}, \lambda=10^{-6} \mu \mathrm{m}, \Delta f=1000 \mathrm{~Hz}$ とすると, $P=1000 \mathrm{~W}$ となりこれが重力波検出器に必要々 されるレーザーのパワーである． $P=1000 \mathrm{~W}$ というのは, 
レーザー加工機で用いるようなレーザーと同程度のパワーで ある，実際には，パワーリサイクリングと呼ばれる技術を用 いることで，実効的に大きなレーザーパワーを用いた状態を 実現できることから, 現在建設中の第二世代と呼ばれる重力 波検出器 (Advanced LIGO (米), Advanced Virgo（伊), LCGT など）では，100〜 $200 \mathrm{~W}$ の出力のレーザー光源を必 要としている. $100 \mathrm{~W}$ という数字は, 通常の干渉計測で用 いられるレーザー光源の出力が $1 \mathrm{~mW}$ 程度で十分であるこ とを考えると, 非常に大きな数字であることがわかる.

従来の重力波検出器では, $10 \mathrm{~W}$ 程度のレーザーが用いら れていた ${ }^{2)}$. 第二世代重力波検出器ではショット雑音の改善 のためにレーザーパワーを $100 \mathrm{~W}$ 程度に増やす。しかし， $100 \mathrm{~W}$ 程度の出力に達すると, 輻射圧雑音と呼ばれるショ ット雑音と同じく真空場の摇らぎによる雑音が重力波検出器 の感度を制限すると考えられている. 輻射圧雑音とは, 光が 鏡で反射する際に運動量の変化分を鏡が受け取ることから, 鏡に入射する光子の数が摇らぐと, 鏡が受ける力が变化し, 鏡の位置が摇らぐことで生じる雑音である. 輻射圧雑音は, レーザーパワーの平方根に比例する.つまり, ショット雑音 $(\propto 1 / \sqrt{P})$ と輻射圧雑音 $(\propto \sqrt{P})$ を考慮すると, 最適なレー

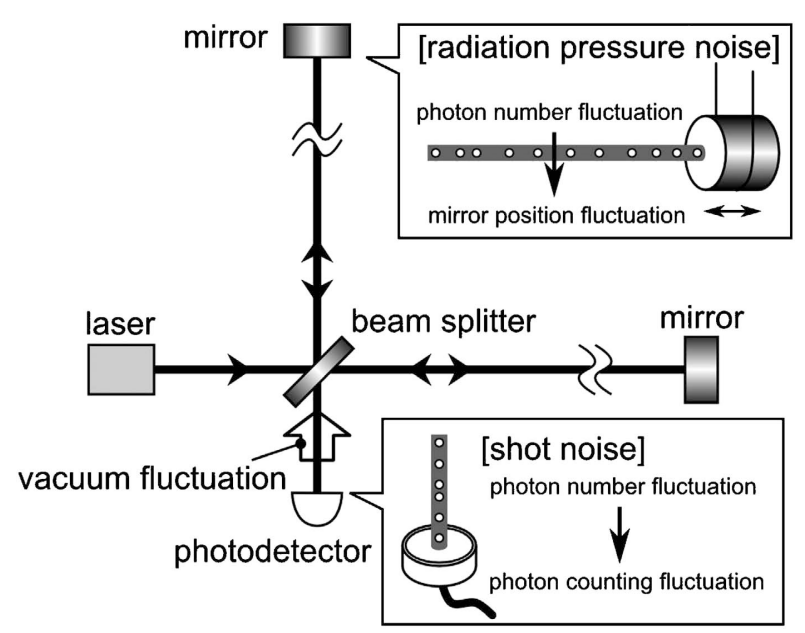

Fig. 2 Shot noise and radiation pressure noise in the interferometric measurement.
ザーパワーが存在することがわかる. 第二世代重力波検出器 では, レーザーパワーに対して最適な状況を実現する．地面 振動や熱雑音などのその他の雑音を極限的に小さくすると, 干渉計型重力波検出器の感度は, 最終的にショット雑音と輻 射圧雑音だけで制限される，つまり，第二世代重力波検出器 では, 究極の干渉計測を実現するといっても過言ではない.

重力波検出器で必要とされるレーザー光源には, 高出力か つ高品質であることに加えて, 出力が変調されている必要が ある、これは, 干渉計をある動作点に保持するために, 必要 な制御信号を取得するためである. LCGTで用いるレー ザー光源では, レーザーの高出力化, 強度 · 周波数の安定 化, 変調などをすべて両立させたシステムである必要があ る. 以降の節で, 日本の次世代重力波検出器「大型低温重力 波望遠鏡 LCGT」で用いるレーザー光源の具体的な構成お よび開発の状況について紹介する.

\section{3. 大型低温重力波望遠鏡で用いるレーザー光源 の開発}

LCGT で用いるレーザー光源の構成を Fig. 3 に示す. Fig. 3 のレーザーシステムにおいて, 厳密な意味でのレー ザーは, 最初の主レーザーと増幅段の部分だけである.しか し, 増幅後のレーザー出力に変調をかけたり, 空間モードを 整形したりなどを含めてレーザーシステムと位置付けて開発 を進めている.

LCGT のレーザーシステムでは, まず比較的低出力では あるが, 低雑音で単一周波数発振するレーザー（主レーザー と呼ぶ）を増幅することで, 出力 $200 \mathrm{~W}$ 程度の単一周波数 出力を実現する. その後, プレモードクリーナーと呼ばれる 光共振器を通すことで, 空間モードのクリーニングおよび高 周波（1 MHz 以上）の雑音の低減を行う，そして光変調器 でレーザー光の変調を行い, モードクリーナーと呼ばれる光 共振器で再度空間モードのクリーニングを行う．そして，干 渉計に入射させる. 以降の節で, 各項目について解説する.

3.1 単一周波数レーザーの高出力化

重力波検出器では, 高出力かつ単一周波数発振するレー ザーを必要とする. そのために, 低出力ではあるが周波数安

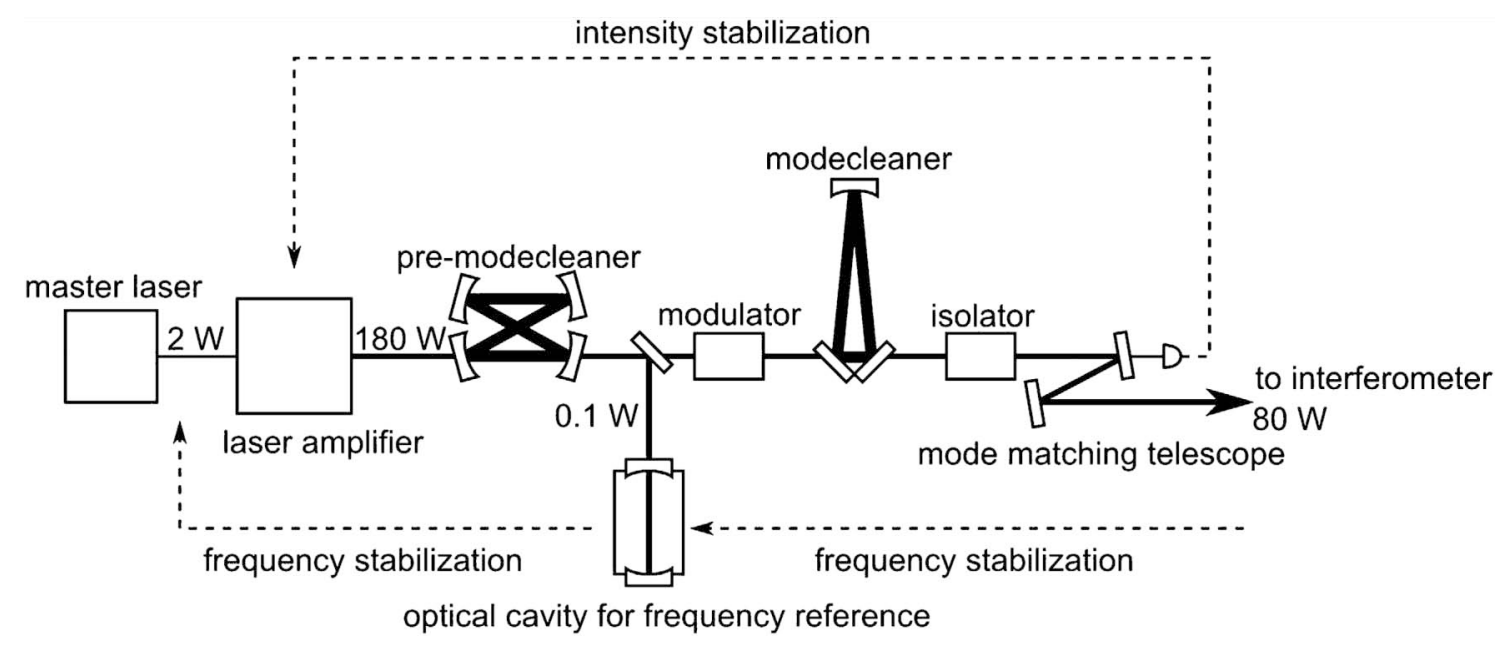

Fig. 3 Schematic diagram of the laser system used in LCGT. 
定度の高い単一周波数レーザー（主レーザー）を増幅するこ とで, 高出力かつ高安定なレーザーを実現する.

3.1 .1 主レーザー

第一世代重力波検出器（LIGO, Virgo, GEO600, TAMA300, CLIO など）の時代から, 主レーザーには Nd : YAGの非平面リング共振器 (Non-Planar Ring Oscillator, NPRO）が使用されてきた. NPRO はレーザー結晶内だけ でモノリシックにリング共振器が構成され, さらに非平面な 光路と外部磁場によるファラデー効果を利用することで, 単 一方向出力で, 非常に安定度の高い単一周波数発振を実現し ている3 .レーザー結晶の温度調節や結晶に貼り付けたピエ ゾ素子を使用することで，レーザー周波数の制御ができるこ とも特徵的である. $\mathrm{Nd}$ : YAG NPRO は最大出力 $2 \mathrm{~W}$ のも のまで市販されており，このような安定なレーザーの中では 比較的出力が大きいが, 重力波検出器での出力の要求を満た すものではない，そのため，このレーザーを増幅して使用す る.

$\mathrm{Nd}$ : YAGレーザー以外にも, 最近ではファイバーレー ザーの技術の向上が著しい. Nd：YAGレーザーとほぼ同じ 波長 $1 \mu \mathrm{m}$ 付近ならイッテルビウムドープファイバー (YDF) レーザー, 波長 $1.5 \mu \mathrm{m}$ 付近ならエルビウムドープファイ バーレーザーの技術が飛躍的に進歩している. 実際に YDF レーザーで, Nd : YAGの NPRO と同程度の雑音特性で, 出力 $100 \mathrm{~mW}$ 程度のものが市販されるようになってきている.

$\mathrm{Nd}$ : YAGの NPRO と比べると出力は劣るが, 高出力化に ファイバー増幅器を用いる場合には, 出力の大きさは十分で あり，かつシステムとしての融合性にも長けている．重力波 検出器用の光源には, これまで固体レーザーが使用されてき たが，このようなファイバーレーザー技術の導入が始まりつ つある。

\section{1 .2 単一周波数レーザーの高出力化}

単一周波数レーザーの高出力化の方法は, 増幅器と注入同 期に分けられる（Fig. 4)。 また，どういうレーザー媒質 （気体, 固体, ファイバー, 色素など）を用いるかというの も大事であり, 重力波検出器で必要とされる, 高出力・低雑 音・単一周波数・単一横モードなどの要求をみたすものとし て，固体レーザーもしくはファイバーレーザーがよく用いら れる。

増幅器とは励起したレーザー媒質だけで構成され, 主レー ザーの光を通すことで, 誘導放出を利用してレーザー光が増 幅される. 候補としては, 固体レーザーによるものと, ファ イバーレーザーによるものがあるが, どちらも共通して, 共 振器長の制御等の精密制御システムを必要としないことが, 後に述べる注入同期と比べた際の利点である.

固体レーザーの増幅器は, 横モードが悪化しやすいという 欠点がある. 重力波検出器では, 高次の横モードは重力波検 出器の感度を悪化させるので, モードクリーナーによって除 去する。つまり, 高次の横モード成分の増加は好ましくな い. なので, 数十ワットまでの中出力までの使用で使われた りする ${ }^{4)}$. 逆に, 高出力増幅時の信頼性が非常に高く, また 簡単な構成で増幅でき, 増幅器の増幅度を強度变調素子とし て使用できるために, 高出力化の最終段だけに使うことにも

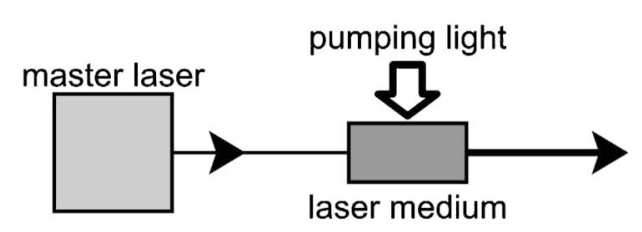

(e.g. Nd:YAG, Nd:YVO4)
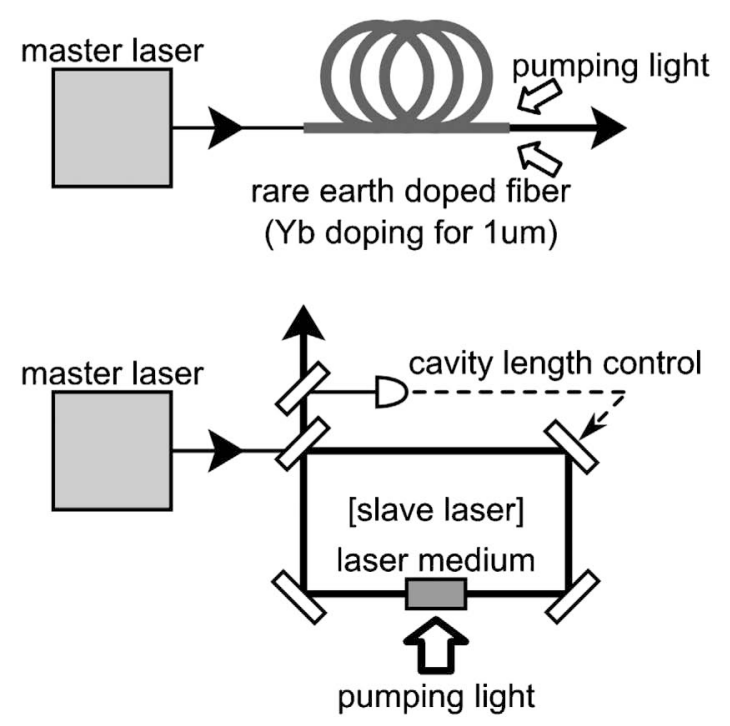

Fig. 4 Laser amplifiers for high-power, single-frequency lasers. (top) Solid-laser amplifier, (middle) fiber laser amplifier, (bottom) injection locking.

適している.

ファイバーレーザーの増幅器では, 長いレーザー媒質を用 意できるために，増幅ゲインを大きくとることができる．ま た，シングルモードファイバーの使用や，大口径ファイバー でも曲げ損失を与えることで高次の横モードを抑えて動作さ せることが可能である. 実際に $100 \mathrm{~W}$ を超える単一周波数 出力を実現した例が報告されている5-7). しかし, 固体レー ザー媒質と比べてファイバーのコア径は小さいので，ファイ バーの損傷が起きたり, ファイバーの持つ非線形効果が雑音 源になるので, 出力を大きくすることが難しい. 長期使用の 観点でも，ダークニングが報告されており，これらの問題の 解決が必要である. しかし, 一度ファイバー内に光を閉じ込 めてしまえば，アライメントの必要がないなど，ハンドリン グの面での利点は非常に大きい。また，ファイバーレーザー は固体レーザーと比べて, 冷却効率が高いので, 冷却機構か らのノイズが小さいことが予想される. 将来的には，ファイ バーレーザータイプの主レーザーと組み合わせることで, ア ライメントフリー, メンテナンスの簡単な, ユーザーフレン ドリーなレーザー光源が実現されると思われる.

注入同期とは, 自然放出光の代わりに, 主レーザーを従 レーザーに注入し, 主レーザーの電場を従レーザー内で誘導 放出により増幅させることで, 主レーザーのモードだけを優 先的に増幅し, 従レーザーを主レーザーの周波数特性に追随 するように発振させる方法である，従レーザーは，それだけ でレーザー発振できるように共振器の構造をもつ. 高出力 レーザーを作る場合, レーザーはその構造が大きくなってし まい, レーザー単体で単一周波数発振させることは難しく, 
エタロンなどの周波数選択素子を挿入する必要がある. しか し, 複数周波数発振するようなレーザーであっても, 注入同 期を行うことでゲインを全て 1 つの周波数に集めることが でき, 単一周波数発振を実現できる. また, 従レーザーは共 振器構造をもつので, 共振器の設計によって単一横モード発 振を実現することができる，実際に，注入同期動作を行うた めには, 主レーザーと従レーザーのモード（周波数, 空間 モード, 偏光）を合わせる必要がある. また，主レーザーを 従レーザーに注入する際, 主レーザーの光が従レーザー共振 器内で共振するように, 従レーザーの共振器長を精密に制御 する必要がある. また, 主レーザーと従レーザー間のアライ メント，モードマッチングなども重要な調整要素となる．良 い性能が得られる分, 構成や調整が複雑になるという久点が ある。

我々は, 固体レーザー $(\mathrm{Nd}: \mathrm{YAG})$ を用いて, 注入同期 による $100 \mathrm{~W}$ 出力の単一周波数発振のレーザーの開発を進 めてきた ${ }^{8)}$. Fig. 5 に装置の概略を示す。主レーザーには 2 $\mathrm{W}$ 出力の Nd : YAG NPRO を用いて, 従レーザーには, 側 面励起の $\mathrm{Nd}$ ：YAGのロッドレーザーを用いている．従 レーザー共振器には, レーザーロッド 2 本と水晶回転子を 組み合わせたレーザーモジュールを 2 台用いている レーザーモジュールの構成により, 高出カレーザーで問題と なる熱複屈折の補償を行っている ${ }^{10,11)}$. Fig. 6 に示す通り, $110 \mathrm{~W}$ 以上の単一周波数出力を実現している. また, レー ザー出力は単一横モード $\left(\mathrm{TEM}_{00}\right)$ (Fig. 7) で, 偏光比も $1: 100$ 以上と非常に高品質なものが得られた ${ }^{12)}$.

\section{2 周波数安定化システム}

重力波検出器は, 2 本の腕が直交したマイケルソン干渉計 を基本としている. マイケルソン干渉計では両腕の長さの変 動の差動成分が検出できる.これに対し, レーザーの周波数 雑音は, 両腕の長さの同相成分として現れる. つまり, 非常 に対称性のよい干渉計であれば, レーザーの周波数摇らぎが 重力波の信号にとって雑音にならない。しかし, 実際の重力 波検出器では, 重力波にとって敏感になるように, 各腕にフ アブリペロー共振器を配置した構成 (Fig. 1) となっており, その結果, 周波数雑音にも敏感な構成となっている. 実際 に, 重力波検出器でよく用いられるレーザー $(\mathrm{Nd}: \mathrm{YAG}$ NPRO）の周波数を特に制御していない状態での周波数雑音 の大きさは, $100 \mathrm{~Hz}$ で約 $10^{2} \mathrm{~Hz} / \mathrm{rtHz}$ である.これに対し,

LCGT で要求されるレーザーの周波数雑音の大きさは，100 $\mathrm{Hz}$ で約 $10^{-8} \mathrm{~Hz} / \mathrm{rtHz}$ であり，抢よそ 100 億分の 1 にレー ザーの周波数雑音を抑える必要がある.

レーザーの周波数摇らぎを 100 億分の 1 にするというと， それだけ安定な周波数の基準を用意する必要があり, 途方も ない話に聞こえるが, 実は, 重力波検出器そのものが周波数 の参照になる.というのも, 重力波は干渉計の直交した 2 本の腕の長さの変動の差動成分として現れる一方, レーザー の周波数摇らぎは, 腕の長さの变動の同相成分に現れるた め, 腕の長さ变動の同相成分はレーザーの周波数雑音として 考えることができ，この同相信号を用いてレーザーの周波数 を制御することで, 非常に周波数雑音の小さなレーザーを実 現できる.

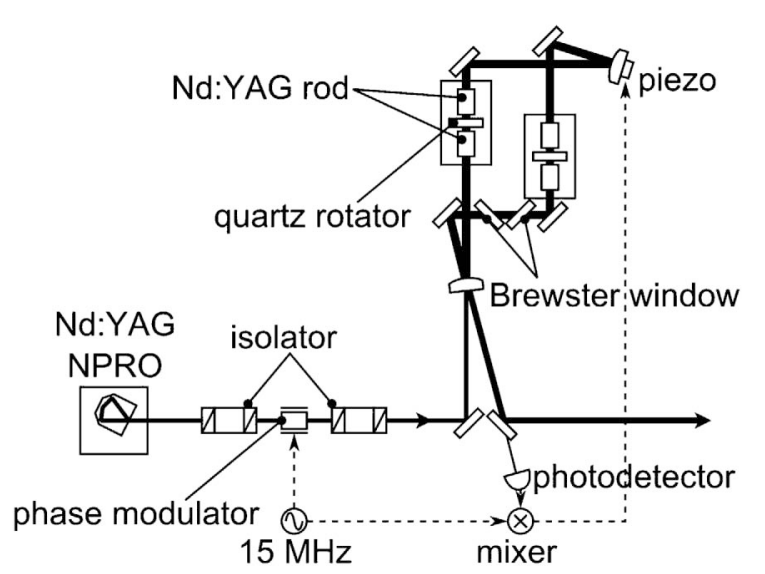

Fig. 5 Schematic diagram of the $100-\mathrm{W}$ injection-locked single-frequency Nd: YAG laser.

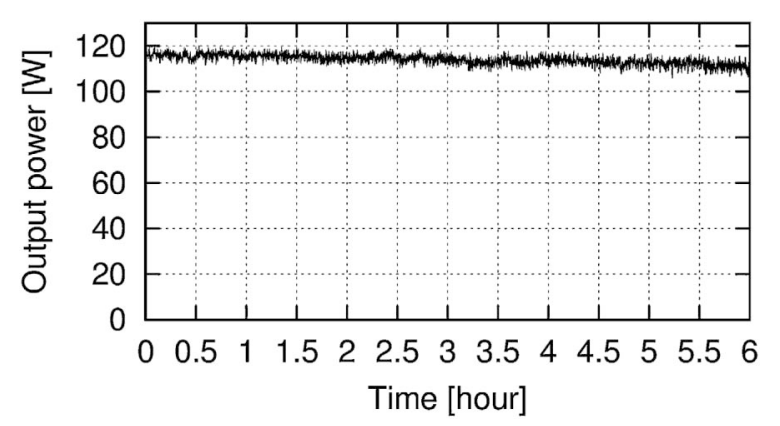

Fig. 6 Output power of the 100-W injection-locked single-frequency Nd : YAG laser.

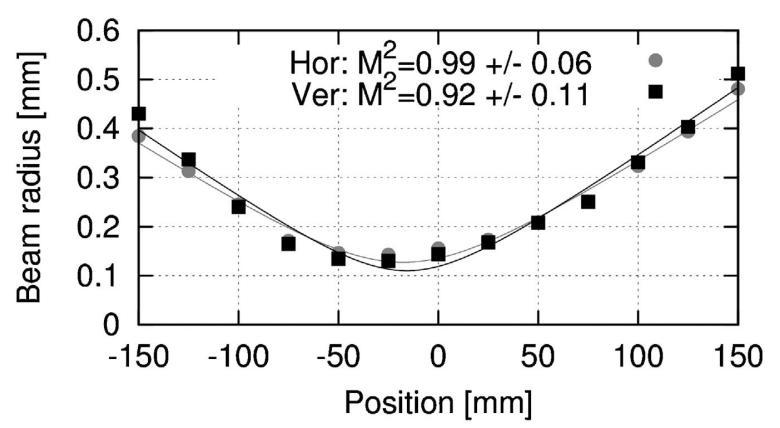

Fig. 7 Output beam profile of the $100-\mathrm{W}$ injection-locked single-frequency Nd : YAG laser.

それでも，基準に対してレーザーの周波数雑音を100億分 の 1 にするのは簡単なことではない。しかも, $100 \mathrm{~W} も の$ 出力のレーザーになると, 熱の問題などで使用できる光学素 子が限定されたりする. そこで, $\mathrm{km}$ スケールの光共振器を テーブルトップに設置する代わりに, 小型の光共振器を周波 数参照として用いて, $100 \mathrm{~W}$ 出力の注入同期型単一周波数 $\mathrm{Nd}$ : YAGレーザーの周波数制御実験を行った. 重力波検出 器での周波数制御には, 広帯域（制御帯域約 $1 \mathrm{MHz}) \cdot$ 高ゲ イン $(100 \mathrm{~Hz}$ で $200 \mathrm{~dB})$ であることが要求される. 注入同 期レーザーの周波数の制御は主レーザーのピエゾ素子抢よび 温度調節端子で行うが，それだけでは $100 \mathrm{kHz}$ を超える広帯 域制御を行うことができない。そこで, 電気光学位相変調器 を用いて高速な制御を行った。高速な制御を実現させるため 
に, この位相変調器には $100 \mathrm{~W}$ もの高出カレーザーを入射 させる必要があり, 变調器に用いる電気光学結晶をきちんと 選択する必要がある. 我々は, 定比組成 $\mathrm{Mg}$ 添加二オブ酸 リチウム（Mg: SLN）を用いた. 通常の $\mathrm{Mg}$ 添加ニオブ酸 リチウムと比べて, Mg : SLN は非常に吸収が小さく, 高出 カレーザーでの用途に適している13). また, 電気光学結晶 の機械的な共振のために, $2 \mathrm{~mm}$ 程度の小さなアパーチャの ものを使用しなければならないので, ビーム径を小さくする 必要があるが, $\mathrm{Mg}$ : SLN 製位相変調器は問題なく使用でき ることが分かった ${ }^{14,15)}$. 周波数制御信号のうち, $1 \mathrm{~Hz}$ 以下 の低周波の信号は主レーザーの温度調節端子に, $1 \mathrm{~Hz}$ 以上 $10 \mathrm{kHz}$ 程度までは主レーザーのピエゾ素子, $10 \mathrm{kHz}$ 以上の 高周波の信号を従レーザーの後に配置した Mg : SLN 製位 相変調器にフィードバックすることで, 制御帯域 $800 \mathrm{kHz}$ も の広帯域な制御を実現した。 をた, $100 \mathrm{kHz}$ 以下の制御ゲイ ンをブーストすることで, $100 \mathrm{~Hz}$ で $300 \mathrm{~dB}$ もの高ゲインな 制御を実現した ${ }^{15)}$. このように, $100 \mathrm{~W}$ もの高出力なレー ザーであっても, 通常の低出力な干渉計用レーザーと同じよ うに周波数制御が可能であることを示した.

\section{3 強度安定化システム}

重力波検出器では干渉計はダークフリンジにロックして使 用し，レーザーの強度雑音は重力波信号に現れないようにす る.しかし, レーザー強度の摇らぎは, 残留变位を介しての 重力波信号にとっての雑音や，ミラーへの輻射圧の摇らぎに なり，干渉信号に現れ重力波信号にとっての雑音になる. LCGT では, 相対強度雑音（強度の摇らぎ $\delta P$ を強度 $P$ で規 格化したもの $\delta P / P$ ) で $10 \mathrm{~Hz}$ で $2 \times 10^{-9} 1 / \mathrm{rtHz}$ という極 限的な強度安定度が要求される.このレベルの強度安定度を 実現するためには，非常に高感度なセンシング技術を必要と する.

レーザーの強度安定化の方法自体は非常にシンプルであ る. 光強度をフォトダイオードで検出して，摇らぎ成分だけ を抽出して摇らぎを抑えるようにフィードバック制御するだ けである.しかし, LCGTで要求される強度雑音レベルを 実現するためには, 強度摇らぎを検出する過程の中で混入す る雑音の対策を十分に行う必要がある.たとえば，空気中で 実験を行うと空気中の塵などによる光の散乱によりレーザー の強度摇らぎではない強度の摇らぎを検出し, フィードバッ ク制御してしまうことになり, 要求されるレベルに到達でき ない．ほかにも，レーザー光の位置の摇らぎがフォトダイ オード表面の量子効率の不均一性とカップルして, 偽の強度 摇らぎを生じたりすることも指摘されている.

LCGT 計画では増幅器の励起電流制御と外部变調器によ る制御を用いて行う予定である。電流引き込み回路を用いた 増幅器の励起電流制御によるレーザーの強度安定化の実証実 験を行い, 制御帯域 $10 \mathrm{kHz}$ 以上の制御を実現している16). また, Advanced LIGO 用の光源の開発を進めているドイッ のグループが, 強度安定化に関する研究を精力的に行ってお り, out-of-loop で $2 \times 10^{-9} 1 / \mathrm{rtHz}$ という非常に高い安定度 を実現している17,18).

\section{4 プレモードクリーナー}

干渉計制御のために, Pound-Drever-Hall 法 ${ }^{19)}$ として知ら

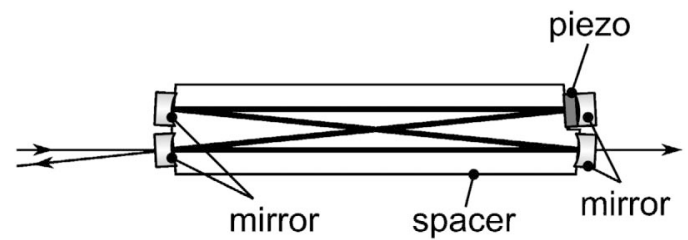

Fig. 8 Pre-modecleaner constructed by four mirrors.

れる変調・復調法を用いる. したがって, 重力波の観測帯域 $(10 \mathrm{~Hz}-1 \mathrm{kHz})$ と同じ周波数のレーザーの強度雑音成分だ けでなく, 変調周波数付近 $(10 \mathrm{MHz} \sim 100 \mathrm{MHz})$ の強度雑 音 $(\mathrm{RF}$ 強度雑音と呼ぶ）の大きさがそのショット雑音レベ ルより大きい場合, 変調・復調を介して, 重力波の観測帯域 の雑音として混入することになる. そのために, RF 強度雑 音の低減も行う必要がある. $\mathrm{RF}$ 強度雑音をアクティブに安 定化することは, 高速に応答するアクチュエータが必要なた めに難しい, そのため, $\mathrm{RF}$ 強度雑音の低減には, 光共振器 の透過光の特性を利用した, パッシブなフィルタリング効果 を利用する ${ }^{20)}$. RF 強度雑音の低減は変調器の前のプレモー ドクリーナーと呼ばれる光共振器で行う. 光共振器は空間 モードの選択性もあるので, このプレモードクリーナーで は, その名前の通り, $\mathrm{RF}$ 強度雑音の低減だけでなく, レー ザー光の空間モードの整形も行う.

$\mathrm{RF}$ 強度雑音の低減性能は, 共振器のフィネス (共振器内 のレーザー増幅度を表すパラメータで鏡の反射率で決まる） が大きく, 共振器長が長い方がよい. しかし, 使用するレー ザーパワーが大きいので, 熱による変形・破損等を考慮する と, フィネスをあまり大きくできない. また, 共振器長を長 くしすぎると，取扱いが非常に難しくなる，そのため， LCGTで用いるプレモードクリーナーでは 4 枚の鏡をス ペーサーに貼り付けた光共振器を用いる (Fig. 8). スペー サーに鏡を貼り付けることで, 鏡の摇れを非常に小さくする ことができる．また，4枚の鏡のうち 1 枚にピエゾ素子をつ けることで, レーザー光が常に共振するように共振器長を制 御する。

\section{5 光変調システム}

LCGT のような第二世代重力波検出器では, 重力波に対 して高感度になるように, Fig. 1 に示す通りたくさんの鏡を 用いた複雑な干渉計の構成を用いる. また, 干渉計をある動 作点で動作させるために，干渉計を構成する各鏡間の距離お よび各鏡の角度を制御する。長さの制御が 5 自由度，また 各鏡の傾きの制御も必要であり, 制御すべき自由度が非常に 多い。これらの制御を行うためには, 動作点からの䛊差を表 す信号（エラー信号）を取得する必要がある. エラー信号の 取得のために, 干渉計に入射させるレーザー光にあらかじめ 変調をかけておく必要がある.

LCGT では制御すべき自由度が多いことから, 変調も複 雑なものが要求される. 通常, 1 つの干渉計や光共振器の制 御には 1 つ位相変調が用いられる。しかし, LCGTでは 位相変調だけでなく, 振幅変調など変調の種類が増え, さら に複数の変調を必要とする21)。そのとき，振幅変調などは 位相変調とは異なり, レーザーパワーの損失を伴う.このこ 


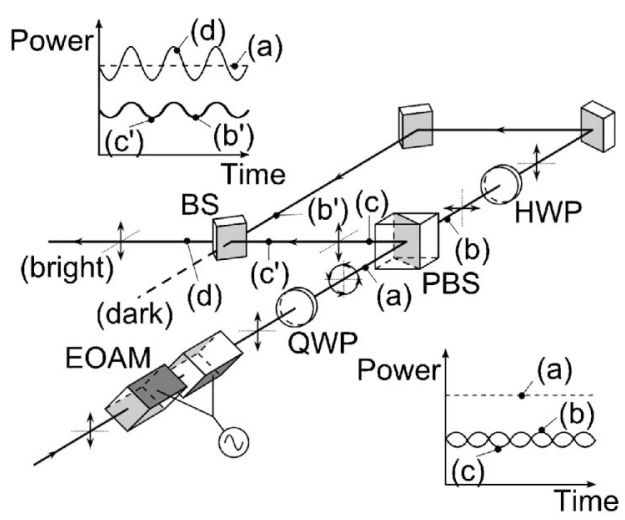

Fig. 9 Schematic diagram of the low loss amplitude modulation system with delayed coherent addition. EOAM; electrooptic amplitude modulator, QWP; quarter wave plate, HWP; half wave plate, PBS; polarizing beam splitter, BS: beam splitter.

とはレーザーの出力への要求を厳しくする. そこで, レー ザーパワーの損失のない振幅変調システムの開発を行った.

Fig. 9 にその概略を示す. 通常の振幅変調の際に損失とな る光に着目し, 時間遅延をつけてコヒーレントに加算するこ とで, 通常は損失となる成分を再利用できることを実験的に 示した ${ }^{22)}$.

\section{6 モードクリーナー}

変調器を通過した光は, 干渉計入射直前でモードクリー ナーによって空間モードを整形（TEM $\mathrm{TE}_{00}$ だけに）する。そ のとき, 光変調器で発生させた変調サイドバンドも通過させ る必要がある. そのために, モードクリーナーのフリースペ クトルレンジ (共振器長で決まる值) が, 変調周波数の整数 倍になるような, 比較的長い共振器長を必要とする. LCGT では一周長約 $53 \mathrm{~m}$ (フリースペクトルレンジは約 $5.6 \mathrm{MHz}$ ) のモードクリーナーを使う予定で，3枚の鏡を使用した三角 共振器を用いる. このような大きな光共振器の場合, 各ミ ラーを独立に振り子で吊って, 真空装置内に配置することが 必須となる。

モードクリーナーを通過した光は, 干渉計からの戻り光を 分離するアイソレータを通過し, 干渉計へと導かれる.

\section{4. ま め}

日本の次世代重力波検出器「大型低温重力波望遠鏡 LCGT」で使用するレーザー光源の開発に関して述べた. 一 言でレーザー光源といっても, その中には主レーザー, 増幅 器, プレモードクリーナー, 光変調器, モードクリーナーお よび強度・周波数の安定化システムがあり, 非常に複雑な技 術の集合体である. 我々はこれまで，これらの技術の開発を 一つずつ進めてきた. 大型低温重力波望遠鏡 LCGT の建設 が始まった今, レーザーに限らず, 低温技術, 鏡の懸架技
術，真空装置などすべての究極技術を神岡鉱山の地に集合さ せ，ぜひ世界初の重力波検出を実現させたい。

\section{謝辞}

本研究の一部は, 文部科学省「光 - 量子科学研究拠点形成 に向けた基盤技術開発 最先端の光の創成を目指したネット ワーク研究拠点プログラム」, および科学研究費補助金（特 別研究員奨励費20・7095）の支援によって実施いたしまし た。

\section{〔文献〕}

1) T. Nakamura, N. Mio and M Ohashi: Jyuryokuha wo Toraeru (Kyoto University Press, Kyoto, 1998)

2) S. T. Yang, T. Imai, M. Oka, N. Eguchi and S. Kubota: Opt. Lett., 21 (1996) 1676.

3) T. J. Kane and R. L. Byer: Opt. Lett., 10 (1985) 65.

4) M. Frede, B. Schulz, R. Wilhelm, P. Kwee, F. Seifert, B. Willke and D. Kracht: Opt. Express, 15 (2007) 459.

5) A. Liem, J. Limpert, H. Zellmer and T. Tunnermann: Opt. Lett., 28 (2003) 1537.

6) Y. Jeong, J. Nilsson, J. K. Sahu, D. B. S. Soh, C. Alegria, P. Dupriez, C. A. Codemard, D. N. Payne, R. Horley, L. M. B. Hickey, L. Wanzcyk, C. E. Chryssou, J. A. Alvarez-Chavez and P. W. Turner: Opt. Lett., 30 (2005) 459.

7) M. Hildebrandt, M. Frede, P. Kwee, B. Willke and D. Kracht: Opt. Express, 14 (2006) 11071.

8) K. Takeno, T. Ozeki, S. Moriwaki and N. Mio: Opt. Lett., 30 (2005) 2110.

9) S. Konno, S. Fujikawa and K. Yasui: Appl. Phys. Lett., 70 (1997) 2650.

10) Q. Lu. N. Kugler, H. Weber, S. Dong, N. Muller and U. Wittrock: Opt. Quantum Eletron., 28 (1996) 28.

11) R. Hua, S. Wada and H. Tashiro: Opt. Commum., 232 (2004) 331.

12) N. Ohmae: Ph.D Thesis, The University of Tokyo (2011).

13) N. Ohmae, K. Takeno, S. Moriwaki and N. Mio: Appl. Phys. Express, 1 (2008) 012005.

14) N. Ohmae, K. Takeno, S. Moriwaki and N. Mio: Appl. Phys. Express, 1 (2008) 092601.

15) N. Ohmae, S. Moriwaki and N. Mio: Rev. Sci. Instrum., 81 (2010) 073105.

16) N. Mio, K. Machida, T. Ozeki and S. Moriwaki: Jpn. J. Appl. Phys., 46 (2007) 5338.

17) F. Seifert, P. Kwee, M. Heurs, B. Willke and K. Danzmann: Opt. Lett., 31 (2006) 2000.

18) P. Kwee, B. Willke and K. Danzmann: Opt. Lett., 34 (2009) 2912.

19) R. W. P. Drever, J. L. Hall, F. V. Kowalski, J. Hough, G. M. Ford, A. J. Munley and H. Ward: Appl. Phys. B, 31 (1983) 97.

20) B. Willke, N. Uehada, E. K. Gustafson, R. L. Byer, P. J. King, S. U. Seel and R. L. Savage Jr.: Opt. Lett., 23 (1998) 1704.

21) F. Kawazoe, A. Sugamoto, V. Leonhardt, S. Sato, T. Yamazaki, M. Fukushima, S. Kawamura, O. Miyakawa, K. Somiya, T. Morioka and A. Nishizawa: Class. Quantum Grav., 25 (2008) 195008.

22) N. Ohmae, S. Moriwaki and N. Mio: Opt. Lett., 36 (2011) 238. 